\title{
Effect of Instructions in Course Book Tasks on Promoting Higher-Order Thinking Skills
}

\author{
Hanoof Khalid Alshaiji ${ }^{1} \&$ Shaima Jamal Al-Saeed ${ }^{1}$ \\ ${ }^{1}$ Language Center, Public Authority for Applied Education and Training, Kuwait \\ Correspondence: Hanoof Khalid Alshaiji, Language Center, Public Authority for Applied Education and \\ Training, College of Technological Studies, Kuwait.
}

Received: October 25, 2021

Accepted: November 29, $2021 \quad$ Online Published: November 30, 2021

doi: $10.5539 /$ elt.v14n12p218

URL: https://doi.org/10.5539/elt.v14n12p218

\begin{abstract}
As stakeholders of educational systems, teachers are urged to participate in social change through the implementation of critical thinking skills into the educational setting. English language teaching has primarily focused on critical thinking, particularly in the recent years. Therefore, teachers are required to examine their teaching materials to ensure that they meet the needs of the 21 st century. This study investigates the extent of implemented higher-order thinking skills using revised Bloom's taxonomy. It examines tasks in course books used at the College of Technological Studies at the Public Authority of Applied Education and Training in Kuwait. The course books examined are Tech Talk at the elementary, pre-intermediate, and intermediate levels. The findings of this study prove that most of the tasks in the sample chosen encourage students' lower cognitive skills. Therefore, syllabus and material designers and teachers should include tasks that foster higher-order cognitive skills. The results are expected to serve as reference for direct language teachers when planning lessons in their course book adaptation and with curriculum development.
\end{abstract}

Keywords: English language learning, 21st-century skills, critical thinking, higher-order thinking skills, course book analysis, revised Bloom's taxonomy

\section{Introduction}

Critical thinking (CT) is one of the most important skills that should be acquired in 21st-century classrooms; it extends beyond EFL (English as a Foreign Language) classrooms to influence learners in other contexts. It has been the subject of many studies, especially in the field of EFL.

CT is currently of high interest because it is an integral skill to be developed in the 21 st century. Moreover, it is the basis for many other important roles, such as reflection, creativity, autonomy, and cultural awareness. For this reason, studies in this area are of great importance because teaching materials should be adapted and developed to grow alongside trends and should consider advances in the educational field in an era of rapid development.

During the process of teaching the English language in a vocational institute in Kuwait, it quickly became evident that the curricula used are lacking in higher-order thinking skills (HOTS). Moreover, such was the case across language levels. Furthermore, students struggle when they encounter HOTS tasks and find them extremely challenging. For instance, this difficulty is observed when they undergo reading comprehension tasks. In general, students reported that answering questions that require inference and comparing or simply expressing opinions are relatively demanding tasks.

Research in this field is abundant. Similar research has been conducted on textbook analysis using Bloom's taxonomy (Fahim, 2011a, 2011b; Mrah, 2017; San, 2020; Sari \& Sakhiyya, 2020; Tutkun, 2012). Previous studies reflect the importance of teaching CT skills, describing and analyzing their contexts to understand the students' needs, which results in improving their social skills, as will be explained later. However, there is a lack of research on evaluating course books used in educational contexts within our region, that is, Kuwait. It is therefore worth examining course books currently used to measure the extent these books promote HOTS.

This research would hopefully shed light on the current situation in Kuwait and would provide a basis for future research within the area in our region. It is important for research in this field to include perspectives from different cultures, and that would be our contribution. 
The research strategy is exploratory and aims to analyze tasks in course books used in the English Department at the College of Technological Studies in terms of CT skills promoted using the revised Bloom's taxonomy (RBT) as a tool. The objective of this research is to show the level of CT skills reached by analyzing the tasks in three course books of Tech Talk series. Therefore, this study addresses the following question.

Do EFL course books (Tech Talk series) used at the English Department at the College of Technological Studies promote HOTS according to RBT?

\section{Literature Review}

\subsection{CT as a 21st Century Skill}

Learners must be equipped with 21 st century skills to succeed in this fast-developing world. According to Senturk and Gökhan (2020, p. 12), 21st century skills include:

Learning and innovation, CT, problem solving, communication and collaboration, information literacy, media and technology, social responsibility, cultural and universal awareness, daily life, occupational tendency and career awareness, using initiative and self-directing, entrepreneurship and self-orientation, leadership of change-transformation and innovation.

Beaumont (2010) describes CT as "a trend well worth keeping in fashion" (p. 447). These skills should be awarded the same importance now as they have been centuries ago, by the great thinkers of those times such as Socrates, Plato, and Aristotle.

Beaumont (2010) states that "students need CT in their academic life" (p. 429). Learning CT skills does not only improve students learning process, which consequently improves its results, but also helps them progress in their careers (Facione, 2020).

Willingham (2007) stated that "[educators] have long noted that school attendance and even academic success are no guarantee that a student will graduate an effective thinker in all situations" (para. 7). Education, as Facione (2020) describes, may be pursued to gain a certificate; but there is liberal education, which he defines as "learning to think for yourself on your own and in collaboration with others." He further explains that liberal education is achieved with people who are not weak critical thinkers no matter the educational degree they hold (p. 24).

CT is linked to critical pedagogy, "which seeks social empowerment and social transformation" (Banegas \& de Castro, 2016, p. 544). Incorporating those skills into ELT would help in increasing social development. Conversely, the absence of those skills may lead to devastating effects on society such as extremism and terrorism (Facione, 2020, p. 26).

To begin discussing these skills, we must first define them. However, as many researchers have stated, defining those skills is not easy considering the complication of its process (Beaumont, 2010, p. 234). Because of its complexity, it needs to be further studied and developed. This is what is felt by many researchers more than 50 years ago and still work on producing frameworks and listing strategies and analyzing them. For the purposes of this paper, we will consider the statement below as the definition of CT:

A statement by Michael Scriven and Richard Paul, presented at the 8th Annual International Conference on CT and Education Reform (Summer, 1987).

$\mathrm{CT}$ is the intellectually disciplined process of actively and skillfully conceptualizing, applying, analyzing, synthesizing, and/or evaluating information gathered from, or generated by, observation, experience, reflection, reasoning, or communication, as a guide to belief and action. In its exemplary form, it is based on universal intellectual values that transcend subject matter divisions: clarity, accuracy, precision, consistency, relevance, sound evidence, good reasons, depth, breadth, and fairness (Scriven \& Paul, 1987, para. 2)

\subsection{Importance of CT to Language Learning}

As CT is involved in all aspects of our lives (Facione, 2020; Beaumont, 2010), the language learning classroom has to keep up with these developments and strive to provide learners with these skills. Although teaching CT is demanding and difficult for students and teachers (Beaumont, 2010, p. 447; Gelder, 2005, p. 42), English language learners will be prevented from success when they do not acquire these skills, as Hawkins (1998) argued.

Furthermore, different ELT approaches emphasized the importance of CT skills such as flipped learning (Zeybek, 2020); layered curriculum (Orkaci, 2020); and STEM (Akınc1, 2020). 
It is important to consider that language skills can be developed by CT. Speaking skills, for instance, are improved through debate. CT can be developed while practicing speaking skills through arguments (Toulmin argumentation) or discussions (Rogerian argumentation) (Wood \& Miller, 2014).

CT skills improve reading skills. Grabe (1991) states that "synthesis and evaluation skills and strategies are critical components of reading abilities" (p. 283). A number of hypotheses addressed the negative effect of instruction on poor comprehension (Snow, 2002). Reading comprehension is achieved through the type of good tasks that promote $\mathrm{CT}$ and that subsequently help in the production of good writing.

The type of instructions teachers give their students affect their production of writing tasks as well. Adler-Kassner and Estrem (2005) define the writing task as stated in WPA "a series of tasks that includes analyzing, evaluating and synthesizing of suitable sources" (p. 61).

Hence, it is clear how CT skills enhance learning language skills. Gelder takes this point further, suggesting that CT skills should be "an explicit part of the curriculum" (Gelder, 2005, p. 43). He clarifies how important it is to study and practice these skills (Beaumont, 2010). These skills are as hard as learning a second language; they need to be practiced to be well used (Gelder, 2005).

Because of this, many countries, including non-western countries such as South Africa, China, Malaysia, Singapore, and Indonesia have included CT into their curriculum and education policy (Ilyas, 2018).

\subsubsection{RBT}

Different researchers created taxonomies (Bloom, 1956), Freeman's (2014), which was based on Sander's, Barret's, Nuttal's, Day and Park's taxonomies. Others listed strategies for CT and frameworks to help teachers developing learners' CT skills as mentioned by Ilyas (2018). The literature review shows how all taxonomies and revisions were generated from Bloom's original work.

Although teachers are "the primary audience of Bloom's taxonomy," Beaumont (2010) adds that the taxonomy addresses anyone in the educational field and textbook authors and publishers are without exemption (p. 429).

Bloom considered the taxonomy as a tool for determining the compatibility of educational objectives, activities, and assessments in units or course or curriculum (Krathwohl, 2002, p. 212).

The original taxonomy that was created by Bloom in 1956 consisted of two domains (Knowledge and Cognitive) that he found serving several educational objectives. Anderson and Krathwohl (2001, p. xxxvii) note that since "the original group always considered the [taxonomy] framework a work in progress, neither finished nor final," they modified the taxonomy and produced what is called "the revised Bloom's taxonomy."

In the revised taxonomy, the cognitive domain was updated as follows. The skills categories were changed from noun to verb forms; three of the main six categories were changed as well: Knowledge to Remember, Comprehension to Understand, Synthesis to Create. Create is placed on top of the framework. The categories are ordered from simple to complex. However, the revised taxonomy is less strict, and it allows the overlap of some categories (Krathwohl, 2002, p. 215) There are six categories in both original and revised taxonomies; only the order of the highest two thinking skills (evaluation and synthesis) was reversed (Figure 1).

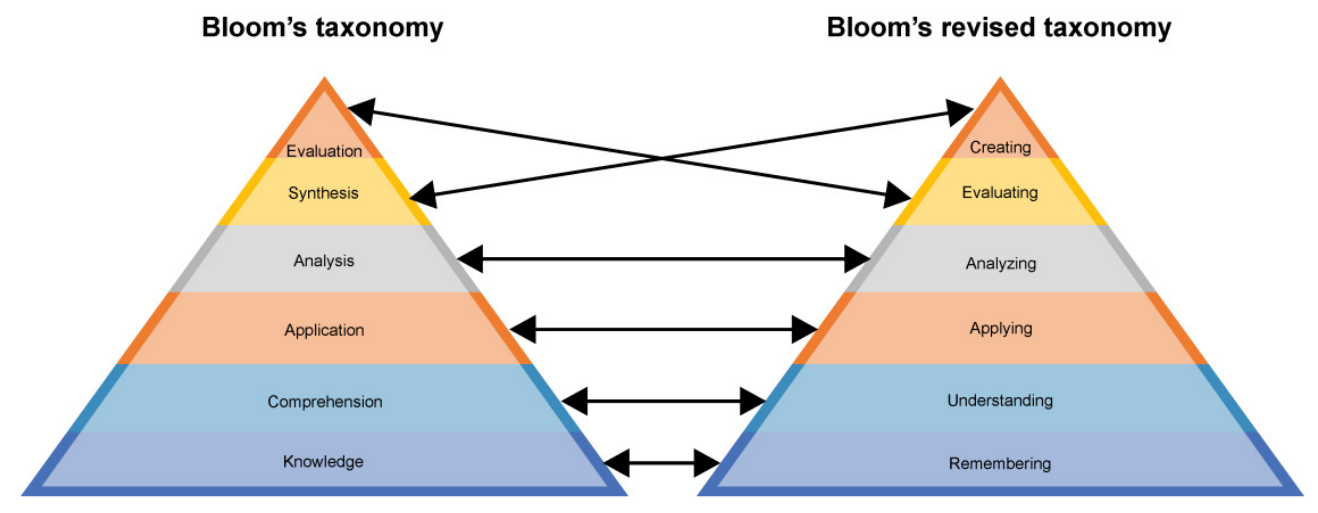

Figure 1. Description of the changes between original Bloom's taxonomy and the revised version (RBT)

Krathwohl (2002) defines the Taxonomy of Educational Objectives as "a framework for classifying statements of what we expect or intend students to learn as a result of instruction" (p. 212). He further describes it as "a scheme for classifying educational goals, objectives, and, most recently, standards." 
HOTS in the RBT are analysis, evaluation, and create. Facione (2020) places the first two among the core CT skills. CT is a complex activity built up out of other skills that are simpler and easier to acquire (Gelder, 2005, p. 42). The skills get more complex when it reaches the top of Bloom's pyramid, which at the same time explains how the preceding skills are easier to acquire.

\section{Methodology}

The research strategy is exploratory, which aims to analyze course books used in College of Technological Studies in CTS Kuwait in terms of CT skills development using RBT as a tool. The course book sample consists of three books in the Tech Talk series (elementary, pre-intermediate, and intermediate). This sample was chosen because this series is taught at all English language courses in CTS at the Public Authority of Applied Education and Training, a higher learning institute in Kuwait.

The books were analyzed using the instrument in Figure 2, RBT Action Verbs. Each task was scrutinized, and action verbs in the task instructions were evaluated using the RVB table given below. They were divided into HOTS: analyze, evaluate, and create, and lower-order thinking skills (LOTS): (remember, understand, and apply). The HOTS were further divided into the three categories, which are the top cognitive skills in the taxonomy. These are defined below.

Krathwohl (2002, p. 215) defines these skills as follows:

Remember: retrieving relevant knowledge from long-term memory.

Understand: determining the meaning of instructional messages, including oral, written, and graphic communication.

Apply: carrying out using a procedure in a given situation.

Analyze: breaking material into constituent parts and detecting how the parts relate to one another and to overall structure or purpose.

Evaluate: making judgments based on criteria and standards.

Create: putting elements together to form a novel, coherent whole or making an original product.

Following that stage, the data were analyzed and categorized to identify theme and patterns in relation to Bloom's taxonomy. We entered the full findings in tables in the appendix, but they are summarized in Table 1. To further clarify the results, the findings were displayed in charts and figures.

These findings will be used to set recommendations as well as criteria for the effective implementation of CT skills in our context

\subsection{Instrumentation}

The following instrument was used:

In their RBT, Anderson and Krathwohl (2001) list common action verbs that are associated with the defined higher and LOTS. Every task in the three course books were compared to this list of action verbs to determine the critical skill being promoted. 


\begin{tabular}{|c|c|c|c|c|c|c|}
\hline Definitions & I. Remembering & II. Understanding & III. Applying & IV. Analyzing & V. Evaluating & VI. Creating \\
\hline $\begin{array}{l}\text { Bloom's } \\
\text { definition }\end{array}$ & $\begin{array}{l}\text { Exhibit memory } \\
\text { of previously } \\
\text { learned material } \\
\text { by recalling facts, } \\
\text { terms, basic } \\
\text { concepts, and } \\
\text { answers. }\end{array}$ & $\begin{array}{l}\text { Demonstrate } \\
\text { understanding of } \\
\text { facts and ideas by } \\
\text { organizing, } \\
\text { comparing, } \\
\text { translating, } \\
\text { interpreting, giving } \\
\text { descriptions, and } \\
\text { stating main ideas. }\end{array}$ & $\begin{array}{l}\text { Solve problems to } \\
\text { news situations by } \\
\text { applying acquired } \\
\text { knowledge, facts, } \\
\text { techniques and } \\
\text { rules in a } \\
\text { different way. }\end{array}$ & $\begin{array}{l}\text { Examine and } \\
\text { break information } \\
\text { into parts by } \\
\text { identifying } \\
\text { motives or } \\
\text { causes. Make } \\
\text { inferences and } \\
\text { find evidence to } \\
\text { support } \\
\text { generalizations. }\end{array}$ & $\begin{array}{l}\text { Present and } \\
\text { defend opinions } \\
\text { by making } \\
\text { judgments about } \\
\text { information, } \\
\text { validity of ideas, } \\
\text { or quality of work } \\
\text { based on a set } \\
\text { of criteria. }\end{array}$ & $\begin{array}{l}\text { Compile } \\
\text { information } \\
\text { together in a } \\
\text { different way by } \\
\text { combining } \\
\text { elements in a } \\
\text { new pattern or } \\
\text { proposing } \\
\text { alternative } \\
\text { solutions. }\end{array}$ \\
\hline Verbs & $\begin{array}{l}\text { - Choose } \\
\text { - Define } \\
\text { - Find } \\
\text { - How } \\
\text { - Label } \\
\text { - List } \\
\text { - Match } \\
\text { - Name } \\
\text { - Omit } \\
\text { - Recall } \\
\text { - Relate } \\
\text { - Select } \\
\text { - Show } \\
\text { - Spell } \\
\text { - Tell } \\
\text { - What } \\
\text { - When } \\
\text { - Where } \\
\text { - Which } \\
\text { - Who } \\
\text { - Why }\end{array}$ & $\begin{array}{l}\text { - Classify } \\
\text { - Compare } \\
\text { - Contrast } \\
\text { - Demonstrate } \\
\text { - Explain } \\
\text { - Extend } \\
\text { - Illustrate } \\
\text { - Infer } \\
\text { - Interpret } \\
\text { - Outline } \\
\text { - Relate } \\
\text { - Rephrase } \\
\text { - Show } \\
\text { - Summarize } \\
\text { - Translate }\end{array}$ & $\begin{array}{l}\text { - Apply } \\
\text { - Build } \\
\text { - Choose } \\
\text { - Construct } \\
\text { - Develop } \\
\text { - Experiment with } \\
\text { - Identify } \\
\text { - Interview } \\
\text { - Make use of } \\
\text { - Model } \\
\text { - Organize } \\
\text { - Plan } \\
\text { - Select } \\
\text { - Solve } \\
\text { - Utilize }\end{array}$ & $\begin{array}{l}\text { - Analyze } \\
\text { - Assume } \\
\text { - Categorize } \\
\text { - Classify } \\
\text { - Compare } \\
\text { - Conclusion } \\
\text { - Contrast } \\
\text { - Discover } \\
\text { - Dissect } \\
\text { - Distinguish } \\
\text { - Divide } \\
\text { - Examine } \\
\text { - Function } \\
\text { - Inference } \\
\text { - Inspect } \\
\text { - List } \\
\text { - Motive } \\
\text { - Relationships } \\
\text { - Simplify } \\
\text { - Survey } \\
\text { - Take part in } \\
\text { - Test for } \\
\text { - Theme }\end{array}$ & $\begin{array}{l}\text { - Agree } \\
\text { - Appraise } \\
\text { - Assess } \\
\text { - Award } \\
\text { - Choose } \\
\text { - Compare } \\
\text { - Conclude } \\
\text { - Criteria } \\
\text { - Criticize } \\
\text { - Decide } \\
\text { - Deduct } \\
\text { - Defend } \\
\text { - Determine } \\
\text { - Disprove } \\
\text { - Estimate } \\
\text { - Evaluate } \\
\text { - Explain } \\
\text { - Importance } \\
\text { - Influence } \\
\text { - Interpret } \\
\text { - Judge } \\
\text { - Justify } \\
\text { - Mark } \\
\text { - Measure } \\
\text { - Opinion } \\
\text { - Perceive } \\
\text { - Prioritize } \\
\text { - Prove } \\
\text { - Rate } \\
\text { - Recommend } \\
\text { - Rule on } \\
\text { - Select } \\
\text { - Support } \\
\text { - Value }\end{array}$ & $\begin{array}{l}\text { - Adapt } \\
\text { - Build } \\
\text { - Change } \\
\text { - Choose } \\
\text { - Combine } \\
\text { - Compile } \\
\text { - Compose } \\
\text { - Construct } \\
\text { - Create } \\
\text { - Delete } \\
\text { - Design } \\
\text { - Develop } \\
\text { - Discuss } \\
\text { - Elaborate } \\
\text { - Estimate } \\
\text { - Formulate } \\
\text { - Happen } \\
\text { - Imagine } \\
\text { - Improve } \\
\text { - Invent } \\
\text { - Make up } \\
\text { - Maximize } \\
\text { - Minimize } \\
\text { - Modify } \\
\text { - Original } \\
\text { - Originate } \\
\text { - Plan } \\
\text { - Predict } \\
\text { - Propose } \\
\text { - Solution } \\
\text { - Solve } \\
\text { - Suppose } \\
\text { - Test } \\
\text { - Theory }\end{array}$ \\
\hline
\end{tabular}

Figure 2. Revised Bloom's action verbs

\subsubsection{Findings}

Table 1. Number of HOTS tasks in Tech Talk elementary, pre-intermediate, intermediate course books

\begin{tabular}{|c|c|c|c|c|c|c|c|}
\hline \multirow[t]{2}{*}{ Unit } & \multicolumn{3}{|c|}{ HOTS Tasks } & \multirow{2}{*}{$\begin{array}{l}\text { Total no. of } \\
\text { HOTS tasks }\end{array}$} & \multirow{2}{*}{$\begin{array}{l}\text { Total no. of } \\
\text { LOTS tasks }\end{array}$} & \multirow{2}{*}{$\begin{array}{l}\text { Total no. of tasks } \\
\text { in course book }\end{array}$} & \multirow{2}{*}{$\begin{array}{l}\text { \% of tasks } \\
\text { with HOTS }\end{array}$} \\
\hline & Analysis & Evaluating & Creating & & & & \\
\hline Elementary & 5 & 2 & 2 & 9 & 377 & 386 & $2.3 \%$ \\
\hline Pre-intermediate & 13 & 14 & 15 & 42 & 300 & 342 & $12.3 \%$ \\
\hline Intermediate & 13 & 9 & 4 & 26 & 273 & 299 & $8.7 \%$ \\
\hline Total & 31 & 25 & 21 & 77 & 950 & 1027 & $7.5 \%$ \\
\hline HOTS breakdown & $40.30 \%$ & $32.50 \%$ & $27.30 \%$ & & & & \\
\hline Percentage & $3 \%$ & $2.40 \%$ & $2 \%$ & $7.4 \%$ & $92.60 \%$ & $100 \%$ & $7.4 \%$ \\
\hline
\end{tabular}

Table 1 displays the findings from analyzing three books in the same series (Tech Talk). The table indicates the numbers of tasks in each of the HOTS and breaks the results down by course book. The number of HOTS is negligible in relation to LOTS, and among the HOTS, analysis has the biggest share of tasks in the series. The findings are illustrated in Figures 3-7 below. 


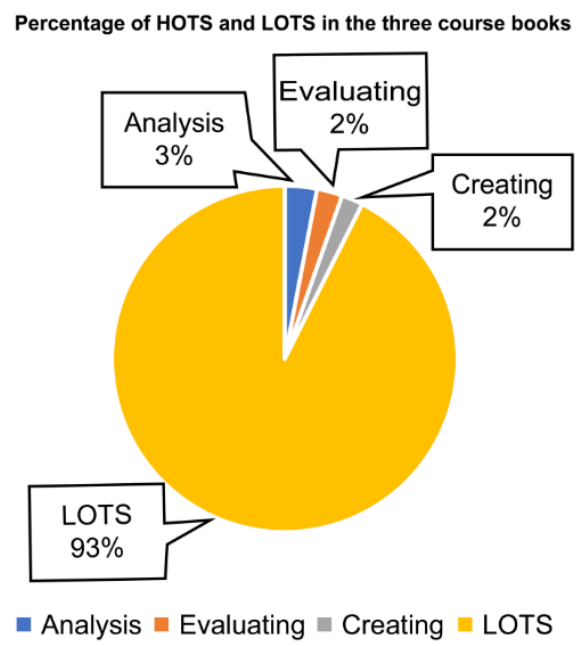

Figure 3. Percentage of HOTS and LOTS in the three course books

Figure 3 displays the percentage of HOTS tasks in relation to LOTS tasks in the three course books examined. As the figure clearly demonstrates, the overwhelming majority of tasks require LOTS, and only a very small percentage $(7 \%)$ requires students to use HOTS. This validates the hypothesis and reflects that most tasks in this series require students to use LOTS. Figure 4 shows more clearly the differences between the numbers of tasks for each HOTS level; it is evident that there was little difference between the numbers of tasks in each level but that the number of tasks decrease as the level of thinking skill increased. These findings are not surprising given that we expected more complex tasks with higher-order skills.

\section{Comparison between}

HOTS levels in tasks

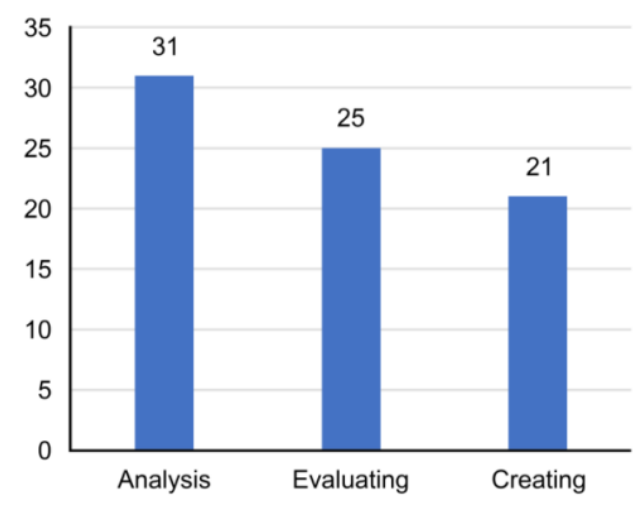

Figure 4. Comparison between HOTS in tasks

Figures 5 and 6 show the HOTS breakdowns for each of the course books. The findings are surprising because we expected that higher course book levels would require more HOTS, but the figures demonstrate that this was not the case. Figure 3 indicates that only $2.3 \%$ of the tasks in the course book required HOTS, and this percentage reached $12.3 \%$ in the pre-intermediate book but decreased significantly in the intermediate book to $8.7 \%$. Figure 6 shows the differences by course book: the elementary book focuses more on analysis, whereas the other two requires a broader variety of HOTS. 


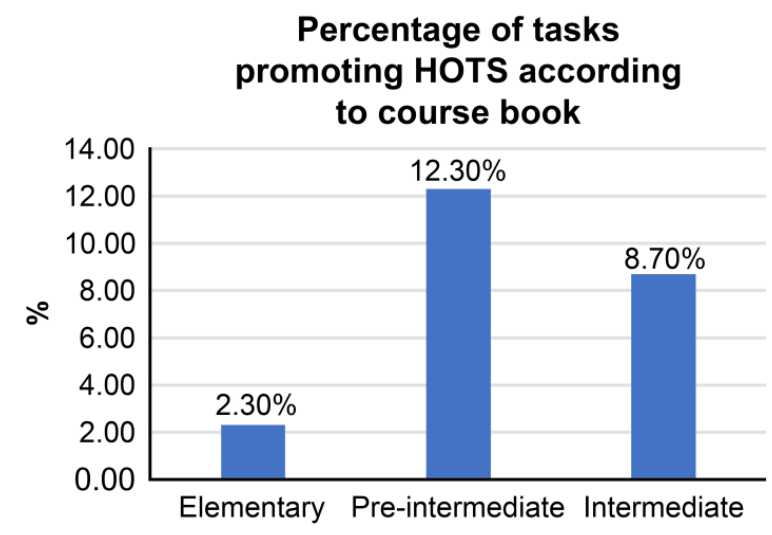

Figure 5. Percentage of tasks promoting HOTS according to course books

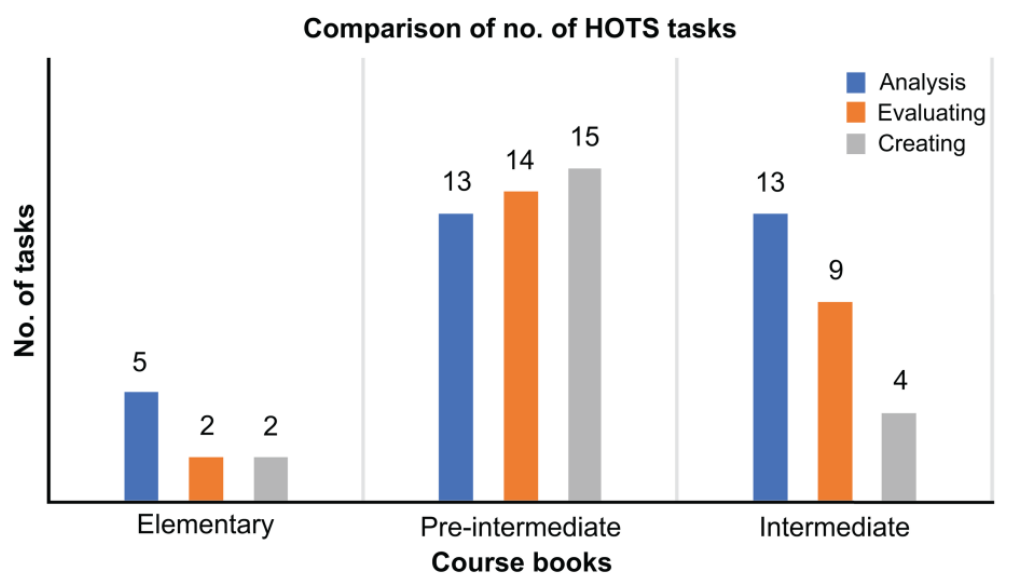

Figure 6. Comparison of number of HOTS tasks

Figure 7 shows clearly that all three course books require predominantly LOTS, and the elementary book in particular significantly lacks HOTS tasks. This leads us to question whether there is a relationship between language level and HOTS use in course books.

\section{Comparison of no. of HOTS tasks according to level}

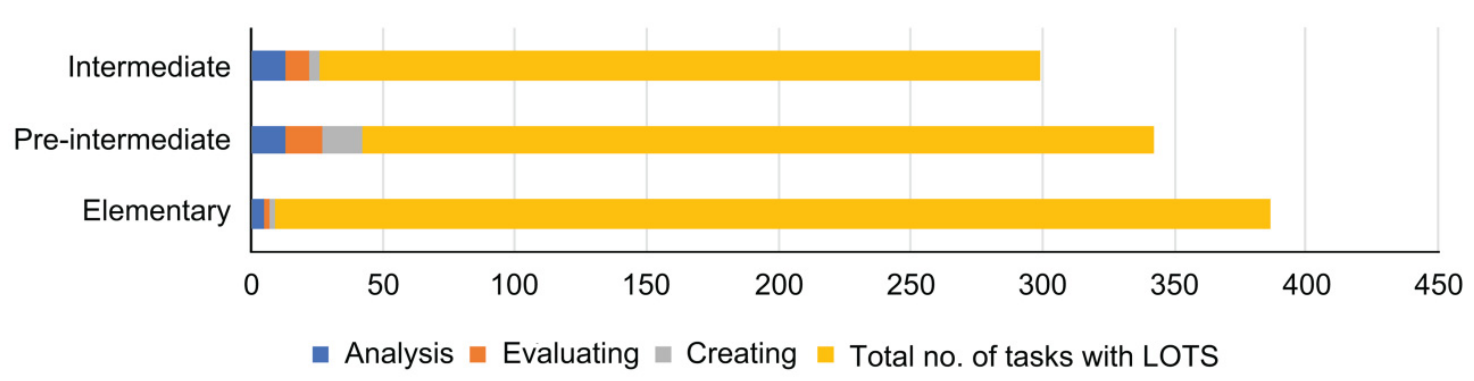

Figure 6. Comparison of the number of HOTS tasks according to course book level

\section{Discussion}

The findings of this study demonstrate how the majority of the tasks in the sample chosen develop students' lower cognitive skills. Analysis, the first level of HOTS, was the skill this task promoted most. It is clear as well that these skills are not promoted equally, with creativity the least stressed. It is difficult to master higher cognitive skills because they are cumulative in nature, and mastering lower levels, even with multiple tasks as we found in these course books, is insufficient to promote CT.

The findings here can be generalized across different contexts because the course books used are from a popular and mainstream series. However, there are limitations that must be considered. First, the series is aimed at technology students, which does limit the scope of the study. In addition, the sample size is small, and a larger 
sample with course books from different publishers would have given more accurate, generalizable results. Furthermore, we relied on a single source of data, but planned mixed methods research incorporating triangulation will provide a comprehensive perspective. However, because of the COVID-19 pandemic and the associated inability to contact students and teachers, we could not collect qualitative data from questionnaires or interviews within the limited timeframe available.

Moreover, using the taxonomy was challenging because there was significant overlap between the levels, and it was sometimes difficult to differentiate between them when categorizing the tasks. Krathwohl (2002) explains that "because the revision gives much greater weight to teacher usage, the requirement of a strict hierarchy has been relaxed to allow the categories to overlap one another." This is an advantage for teachers using the taxonomy for materials development purposes but a hindrance for researchers using it for study purposes (p. 215).

\section{Conclusion and Recommendations}

Not only do CT skills affect students' academic lives but they extend beyond that to make students liberally educated and enable them to actively participate in social transformation. As language educators, we should consider these skills when setting our curriculum objectives, course material, and assessments.

The results of this study encourage syllabus and material designers as well as teachers to incorporate tasks that promote higher-order cognitive skills into their curricula. Following through on this recommendation will entail that teachers be critical thinkers themselves and that they reflect on their teaching contexts. This could mean training and professional development courses to enhance teachers' skills in this area. An additional recommendation related to the previous suggestion is providing a practical framework for implementing CT skills in the EFL classroom to adapt or supplement course books.

\section{Acknowledgments}

Both authors have equally contributed to the study. We are grateful to PAAET for facilitating the study. We would like to extend our gratitude to the Enago team for their services.

\section{References}

Adler-Kassner, L., \& Estrem, H. (2005). Critical thinking, reading, and writing: A view from the field. In S. Harrington, K. Rhodes, R. O. Fischer, \& R. Malenczyk (Eds.), The outcomes book: Debate and consensus after the WPA outcomes statement (pp. 60-70). Logan, UT: Utah State University Press. https://doi.org/10.2307/j.ctt46nwgv.12

Akınc1, B. (2020). STEM for English language teaching. In S. Orakc1 (Ed.), Paradigm shifts in 21st century teaching and learning (pp. 99-117). Turkey: IGI Global. https://doi.org/10.4018/978-1-7998-3146-4.ch007

Anderson, L. W., \& Krathwohl, D. R. (2001). A taxonomy for learning, teaching, and assessing: A revision of Bloom's taxonomy of educational objectives. New York, NY: Longman.

Banegas, D. L., \& Villacañas de Castro, L. S. (2016). Criticality. ELT Journal, 70(4), 455-457. https://doi.org/10.1093/elt/ccw048

Beaumont, J. (2010). A sequence of critical thinking tasks. TESOL Journal, 1(4), 427-448. https://doi.org/10.5054/tj.2010.234763

Bloom, B. S. (1956). Taxonomy of educational objectives. Handbook 1: Cognitive domain.

Facione, P. A. (2020). Critical thinking: What it is and why it counts. Retrieved from https://www.insightassessment.com/wp-content/uploads/ia/pdf/whatwhy.pdf

Fahim, M., \& Sa'eepour, M. (2011). The impact of teaching critical thinking skills on reading comprehension of Iranian EFL learners. Journal of Language Teaching and Research, 2(4), 867-874. https://doi.org/10.4304/jltr.2.4.867-874

Freeman, D. (2014). Reading comprehension questions: The distribution of different types in global EFL textbooks. In N. Hardwood (Ed.), English language teaching textbooks: Content, consumption production (pp. 72-110). London: Palgrave Macmillan. https://doi.org/10.1057/9781137276285_3

Gelder, T. V. (2005). Teaching critical thinking: Some lessons from cognitive science. College Teaching, 53(1), 41-48. https://doi.org/10.3200/CTCH.53.1.41-48

Grabe, W. (1991). Current developments in second language reading research. TESOL Quarterly, 25(3), 375-406. https://doi.org/10.2307/3586977 
Hawkins, M. R. (1998). Apprenticing nonnative speakers to new discourse communities. TESOL Quarterly, 32(1), 129-132. https://doi.org/10.2307/3587908

Hollett, V. (2003). Tech talk, elementary-student book. Oxford, UK: Oxford University Press.

Hollett, V. (2005). Tech talk, pre-intermediate- student book. Oxford, UK: Oxford University Press.

Hollett, V., \& Sydes, J. (2009). Tech talk, intermediate-student book. Oxford, UK: Oxford University Press.

Ilyas, H. P. (2018). The quest for critical thinking framework in ELT. Celt: A Journal of Culture, English Language Teaching and Literature, 18(8), 310-332. https://doi.org/10.24167/celt.v18i2.685

Krathwohl, D. R. (2002). A revision of Bloom's taxonomy: An overview. Theory Into Practice, 41(4), 212-218. https://doi.org/10.1207/s15430421tip4104_2

Mrah, I. (2017). Developing higher order thinking skills: Towards a rethinking of EFL course books in Moroccan high schools. Journal of English Language Teaching and Linguistics, 2(3). https://doi.org/10.21462/jeltl.v2i3.79

Orakc1, Ş. (2020). The importance of layered curriculum in learning-teaching process. In Ş. Orakc1 (Ed.), Paradigm Shifts in 21st Century Teaching and Learning (pp. 202-217). IGI Global. https://doi.org/10.4018/978-1-7998-3146-4.ch013

San, K. M. (2020). The cognitive thinking levels called for by the instructions in the course book Globa B1. Journal of Myanmar Academy of Arts and Science. Arts Sci., XVIII(7), 19-26.

Sari, R. N., \& Sakhiyya, Z. (2020). The textbook analysis on students' book of Symphony 1 English course book for Senior High School Grade X viewed from higher order thinking skills. ELT Forum: Journal of English Language Teaching, 9(2), 97-106. https://doi.org/10.15294/elt.v9i2.38711

Scriven, M., \& Paul, R. (1987). Defining critical thinking. 8th Annual International Conference on Critical Thinking and Education Reform. Retrieved https://www.criticalthinking.org/pages/defining-critical-thinking/766

Şentürk, C., \& Gökhan, B. (2020). An overview of learning and teaching from the past to the present: New learning and teaching paradigms in the 21 st century. In S. Orakc1 (Ed.), Paradigm shifts in 21st century teaching and learning (pp. 1-19). Turkey: IGI Global. https://doi.org/10.4018/978-1-7998-3146-4.ch001

Shirkhani, S., \& Fahim, M. (2011). Enhancing critical thinking in foreign language learners. Procedia - Social and Behavioral Sciences, 29, 111-115. https://doi.org/10.1016/j.sbspro.2011.11.214

Snow, C. E. (2002). A research agenda for improving reading comprehension. In Reading for Understanding: toward an R\&D Program in Reading Comprehension (pp. 29-60). Santa Monica, CA; Arlington, VA; Pittsburgh, PA: RAND Corporation. Retrieved from https://www.jstor.org/stable/10.7249/mr1465oeri.12

Willingham, D. T. (2007). Critical thinking: Why it is so hard to teach? Retrieved from https://eduq.info/xmlui/bitstream/handle/11515/19710/Crit_Thinking.pdf

Wood, N. V., \& Miller, J. S. (2014). Perspective on Argument (8th ed.). Upper Saddle River, NJ: Pearson.

Zeybek, G. (2020). Flipped learning. In Ş. Orakcı (Ed.), Paradigm Shifts in 21st Century Teaching and Learning (pp. 158-180). Turkey: IGI Global. https://doi.org/10.4018/978-1-7998-3146-4.ch011

\section{Copyrights}

Copyright for this article is retained by the author(s), with first publication rights granted to the journal.

This is an open-access article distributed under the terms and conditions of the Creative Commons Attribution license (http://creativecommons.org/licenses/by/4.0/). 